\title{
DAMPAK PENAMBANGAN BATU GUNUNG DI DESA MERANGIN KECAMATAN KUOK DITINJAU MENURUT EKONOMI ISLAM
}

\author{
Meri Yuliani* \\ *Fakultas Ilmu Sosial, Universitas Islam Kuantan Singingi \\ Jl. Gatot Subroto KM 7 Kuantan Singingi, 29566 \\ e-mail: meriyuliani6@gmail.com
}

\begin{abstract}
Abstrak : Pertambangan yang terletak di desa Merangin Kecamatan Kuok ini berupa batu gunung yang harus dimanfaatkan bagi kemakmuran dan kesejahteraan masyarakat. Tetapi pada realitanya, usaha pertambangan batu gunung di Desa Merangin Kecamatan Kuok banyak menimbulkan dampak negatif di bandingkan dampak positif. Hal ini terkait dengan ekonomi masyarakat, lingkungan hidup dan kehidupan sosial. Dampak negatif yang ditimbulkan penambangan batu gunung di Desa Merangin ini terutama pada kerusakan lingkungan yang dapat membahayakan kehidupan Masyarakat. Dari hasil penelitian dapat disimpulkan bahwa pelaksanaan penambangan batu gunung di Desa Merangin menggunakan alat-alat yang sederhana (secara manual)dan ativitas penambangan ini tidak memiliki izin dari pemerintah Kabupaten Kampar. Penambangan batu gunung di Desa merangin ini tidak hanya menimbulkan dampak positif tetapi juga menimbulkan dampak negatif terutama pada kerusakan lingkungan yang dapat membahayakan kehidupan masyarakat. Menurut ekonomi Islam, penambangan batu gunung di Desa Merangin Kecamatan Kuok tidak sesuai dengan prinsip ekonomi Islam, ditemukan indikasi-indikasi yang bertentangan dengan prinsip ekonomi Islam, seperti melanggar kaidah-kaidah dalam berproduksi dan proses produksi.
\end{abstract}

Kata Kunci : Dampak, Penambangan, Ekonomi Islam 


\section{PENDAHULUAN}

Alam semesta beserta isinya diciptakan Allah agar dapat dipergunakan untuk mencukupi kebutuhan manusia. Allah telah menganugerahkan karunia yang besar kepada manusia, menciptakan langit dan bumi untuk manusia, untuk diambil manfaatnya sehingga manusia dapat menjaga kelangsungan hidupnya dan agar berbakti kepada Allah penciptanya, kepada keluarga dan masyarakat. Potensi sumber daya mineral di Indonesia tersebar tidak merata di berbagai wilayah. Agar potensi ini dapat diusahakan untuk digunakan sebagai pendukung pembangunan yang berkelanjutan perlu dilakukan usahausaha tertentu. (Haryanto, 2008 : 57)

Pertambangan adalah rangkaian kegiatan dalam rangka upaya pencarian, penambangan (penggalian), pengolahan, pemanfaatan, dan penjualan bahan galian. Usaha pertambangan merupakan usaha pemanfaatan bumi, air, dan kekayaan alam meliputi eksplorasi, eksploitasi, pengolahan, pemurnian, pengangkutan dan penjualan. (Salim, 2007 : 53). Sehubungan dengan ini pemerintah Republik Indonesia telah mengeluarkan Undang-undang tentang Batuan (Batu Gunung) yaitu Undang-undang No 4 tahun 2009 yang mana sebelumnya diatur dalam Undang-undang No 11 tahun 1967 tentang ketentuan-ketentuan pokok pertambangan. Menurut undang-undang No. 4 Tahun 2009 tentang Pertambangan Mineral dan Batu Bara bahwa penambangan batu gunung ini termasuk kedalam golongan yang kelima yaitu golongan batuan yang pengelolaannya harus ada surat izin

Pertambangan dari pemerintah daerah yaitu pemberian izin usaha pertambangan (IUP). Pertambangan di Indonesia dikuasai oleh negara sesuai tuntutan pasal 33 UUD 1945. Atas dasar itulah jika ada pihak lain yang mengelola dan memanfaatkannya haruslah melakukan kerja sama dengan pemerintah. (Faried : 1997 :67) Karena itulah kegiatan penambangan batu gunung itu harus ada izin dari pemerintah. Sedangkan Kegiatan penambangan batu gunung yang dilakukan di Desa Merangin ini tidak berizin.

Pemerintah kabupaten Kampar tidak memberikan izin penambangan batu gunung karena selain merusak lingkungan juga sangat membahayakan masyarakat sekitar karena penambangan batu gunung ini dilakukan di tepi jalan Lintas RiauSumbar. Namun kenyataanya, pihak penambang tetap menjalankan aktivitas penambangan batu tanpa izin di Desa Merangin ini dengan menggunakan alat manual. Kegiatan penambangan ini apabila dibiarkan akan menimbulkan kerusakan pada lingkungan sehingga mempengaruhi atau menyebabkan bencana alam lainnya misalnya longsornya tanah di tepi jalan yang akan mengakibatkan terhambatnya jalan transportasi dan juga bisa membahayakan nyawa manusia. Sebagian besar yang melakukan penambangan batu gunung ini adalah masyarakat sekitar yang tinggal di daerah pertambangan. Mereka memilih untuk melakukan penambangan batu gunung ini sebagai jalan untuk melanjutkan hidup atau menopang ekonomi keluarga.

Manusia sebagai makhluk hidup yang berinteraksi dengan lingkungan alam sekitarnya, dalam interaksinya tersebut manusia dapat mempengaruhi lingkungan dan mengusahakan sumber daya alam untuk mempertahankan dan memenuhi kebutuhan hidupnya, manusia diberi kemampuan untuk mengolah alam sebagai sumber kehidupan. Besar kecilnya kebutuhan hidup individu kadang ditentukan oleh status dan lingkungan pergaulan. Apapun rezeki yang diperoleh seseorang tidak lain berasal dari sumber daya alam yang telah diciptakan oleh Allah sebelum manusia ada dimuka bumi ini. 
Pengelolaan lingkungan hidup bertujuan untuk tercapainya keselarasan hubungan antara manusia dengan lingkungan hidup sebagai tujuan pembangunan manusia Indonesia selanjutnya, terkendalinya pemanfaatan sumber daya secara berwawasan lingkungan untuk kepentingan generasi sekarang dan akan datang, terlindunginya negara terhadap dampak kegiatan diluar wilayah negara yang menyebabkan kerusakan dan pencemaran lingkungan. (http://gagasanhukum.Wordpress.com/2 013/07/14/rakyat-punya-hakmenikmati-lingkungan-sehat)

Usaha penambangan itu sebetulnya bagus karena memanfaatkan sumber daya alam sebuah karunia Allah SWT, tetapi banyak hal-hal yang tidak diperhatikan oleh pengelola seperti halnya lingkungan sekitar usaha penambangan ini.

Setiap pekerjaan itu mempunyai dampak positif dan negatif. Ada beberapa dampak positif yang ditimbulkan dari penambangan batu gunung ini diantaranya terserapnya tenaga kerja, memunculkan usaha warung-warung kecil di areal penambangan dan memudahkan masyarakat setempat untuk mendapatkan batu gunung sebagai bahan bangunan. Sedangkan dampak negatif dari penambangan batu gunung ini adalah kerusakan lingkungan dan bisa membahayakan nyawa manusia apabila tejadinya tanah longsor yang diakibatkan dari penambangan batu gunung tersebut.

\section{TINJAUAN PUSTAKA}

\section{Tinjauan Islam Tentang Produksi dan Pengelolaan Sumber Daya Alam}

Dalam sistem ekonomi Islam, kata "Produksi" merupakan salah satu kata kunci yang terpenting, karena dari konsep dan gagasan produksi ditekankan bahwa tujuan utama ingin dicapai kegiatan ekonomi yang dteorisasikan sistem ekonomi Islam adalah utuk kemaslahatan individu, dan kemaslahatan masyarakat secara berimbang. (Said, 2008 : 62).
Produksi menurut As-sadar adalah usaha mengembangkan sumber daya alam agar lebih bermanfaat bagi manusia. sedangkan menurut urub Abdul Salam adalah usaha mengekploitasi sumber daya alam agar dapat menghasilkan manfaat ekonomi. (Mawardi, 2007 : 65)

Beberapa prinsip yang perlu diperhatikan dalam produksi, antara lain dikemukakan Muhammad al-Mubarak seperti yang dikutip oleh mawardi, sebagai berikut :

a. Dilarang memproduksi dan memperdagangkan komoditas yang tercela karena bertentangan dalam syariah.

b. Dilarang melakukan kegiatan produksi yang mengarah kepada kezaliman, seperti riba dimana kezaliman menjadi illat hukum bai haramnya riba.

c. Segala bentuk penimbunan terhadap barang-barang kebutuhan masyarakat, adalah dilarang sebagai perlindungan syariah terhadap konsumen.

d. Memelihara lingkungan. (Karim, 2007 : 102)

Dalam memproduksi juga harus memperhatikan kaidah-kaidah yang berlaku antara lain :

a. Memproduksi barang dan jasa yang halal pada setiap tahapan produksi.

b. Mencegah kerusakan di muka bumi termasuk membatasi populasi keserasian dan ketersedian sumber daya alam.

c. produksi dimaksudkan untuk memenuhi kebutuhan individu dan masyarakat serta mencapai kemakmuran. Kebutuhan yang harus dipenuhi harus berdasarkan prioritas yang ditetapkan agama, yakni terkait dengan kebutuhan akidah/agama, terpeliharanya nyawa, akal dan keturunan/kehormatan serta untuk kemammuran material.

d. Produksi di dalam Islam tidak dapat dipisahkan dari tujuan kemandirian umat untuk itu hendaknya umat memilliki berbagai kemampuan,

SYARIKAT : Jurnal Rumpun Ekonomi Syariah Volume 1, Nomor 2, Desember 2018 
keahlian dan prasarana yang memungkinkan terpenuhinya kebutuhan spritual dan material.

e. Meningkatkan kualitas sumber daya manusiabaik kuaitas spritual terkait etos kera, intelektual, kreatifitasnya.

Bumi dengan segala isinya disiptakan Allah untuk kepentingan manusia agar dapat dinikmati dan dimanfaatkan secara maksimal. Hendaknya, sumber daya ekonomi didayagunakan sebaik-baiknya dan segala sesuatu diaga agar tidak terbuang percuma. Sumber daya ini perlu dijaga karena ia merupakan amanat yang wajib dilestarikan dan nikmat yang harus disyukuri dengan cara menggunaknnya sebaik-baiknya. (Qardhawi, 2000 : 132).

Dalam pemanfaatan sumber daya alam, Islam memberikan petunjuk sebagai berikut, pertama, Al-qur'an dan al-sunah memberi peringatan bahwa alam telah ditundukkan untuk manusia sebagai salah satu sumber rezeki. Kedua, manusia adalah khalifah Allah, yang bertugas mengatur, memanfaatkan dan memberdayakan alam, sedangkan pemilik yang hakiki adalah Allah Swt. Ketiga, Islam mengizinkan pemanfaatan sumber daya alam baik untuk kepentingan seseorang atau orang banyak. Keempat, manusia dalam memanfaatkan sumber daya alam harus memperhatikan dan mentaati hukum-hukum yang ditetapkan oleh Allah, yaitu menjaga, memelihara dan memakmurkannya, bukan merusak alam yang mengakibatkan punanya keasrian dan keindahan alam semesta. (Mujahidin, $2007: 41$ )

\section{Pertambangan.}

Peradaban manusia awalnya
ditandai dengan usaha dibidang
pertanian, kemudian diikuti oleh usaha di
bidang pertambangan. Sejak zaman
prasejarah pertambangan sudah menyatu
dan menjadi bagian penting kehidupan
manusia. Pertambangan telah ada sejak
450.000 tahun yang lalu. Manusia dari
zaman purba (paleolitik) telah

menggunakan batu yang digali dari tanah, kemudian dibentuk dengan teknik sederhana menjadi peralatan yang mereka perlukan. (Haryanto, 2008 : 5)

Pertambangan batu gunung atau batu alam disebut pertambangan Rakyat. Pertambangan rakyat adalah usaha pertambangan bahan galian strategis dan vital yang dilakukan oleh rakyat setempat yang bertempat tinggal di daerah bersangkutan untuk penghidupan mereka sendiri sehari-hari yang diusahakan secara sederhana.

Menurut undang-undang No. 4 Tahun 2009 tentang Pertambangan Mineral dan Batubara bahwa Pertambangan adalah sebagian atau seluruh tahapan kegiatan dalam rangka penelitian, pengelolaan, dan pengusahaan mineral atau batubara yang meliputi penyelidikan umum, eksplorasi, studi kelayakan bisnis, kontruksi, penambangan, pengolahan dan pemurnian, pengangkutan, dan penjualan, serta kegiatan pasca tambang.

Kegiatan pertambangan berupa penggalian, eksploitasi sumber energi, serta mineral, baik metalik maupun nonmetalik. Pertambangan mineral metal adalah pertambangan yang menghasilkan tembaga, nikel, timbal, besi, aluminium, bauksit, mangan dan sebagainya. Sementara itu, pertambangan nonmetal menghasilkan semen, sulfur, bentonit, yodium, marmer, granit, gips, batu mulia (opal, berlian, dan seterusnya). Pertambangan golongan $\mathrm{C}$ adalah pertambangan yang diperlukan untuk pembangunan seperti pasir, batu, kerikil, lempung, dan hasil pertambangan lain yang juga mempunyai arti penting.

Penggolongan bahan galian menurut Undang-Undang No. 11 Tahun 1967 tentang Ketentuan-Ketentuan Pokok Pertambangan, dibagi menjadi 3 (tiga) golongan, yaitu:

1. Bahan galian golongan $\mathrm{A}$, yaitu bahan galian golongan strategis. Yang dimaksud strategis adalah strategis 
bagi pertahanan/keamanan negara atau bagi perekonomian negara;

2. Bahan galian golongan $B$, yaitu bahan galian vital, adalah bahan galian yang dapat menjamin hajat hidup orang banyak;

3. Bahan galian $\mathrm{C}$, yaitu bahan galian yang tidak termasuk kedalam golongan $\mathrm{A}$ dan B.

Bahan galian apa saja yang termasuk ke dalam masing-masing golongan tersebut diatur berdasarkan ketentuan pengelompokan lebih rinci, dalam Peraturan Pemerintah No. 27 Tahun 1980, yaitu:

1. Bahan galian golongan $\mathrm{A}$ atau bahan galian strategis, terdiri dari:

a. Minyak bumi, bitumen cair, lilin bumi, dan gas alam;

b. Bitumen padat, aspal;

c. Antrasit, batu bara, batu bara muda;

d. Uranium, radium, thorium, dan bahan-bahan radio aktif lainnya;

e. Nikel, kobalt;

f. Timah.

2. Bahan galian golongan $B$ atau bahan galian vital, terdiri dari:

a. Besi, mangan, molibdenum, khrom, walfran, vanadium, titanium;

b. Bauksit, tembaga, timbal, seng;

c. Emas, platina, perak, air raksa, intan;

d. Arsen, antimon, bismut;

e. Yttrium, rhutenium, crium, dan logam-logam langka lainnya;

f.Berrillium, korundum, zirkon, kristal kwarsa;

g. Kriolit, flouspar, barit;

h. Yodium, brom, khlor, belerang.

3. Bahan galian golongan $\mathrm{C}$ atau bahan galian industri, terdiri dari:

a. Nitrat, phosphate, garam batu;

b. Asbes, talk, mike, grafit, magnesit;

c. Yarosit, leusit, tawas (alam), oker;

d. Batu permata, batu setengah permata; e. Pasir kwarsa, kaolin, feldspar, gips, bentonite;

f. Batu apung, teras, obsidian, perlit, tanah diatome;

g. Marmer, batu tulis;

h. Batu kapor, dolomit, kalsit;

i. Granit, andesit, basal, trakkit, tanah liat, dan pasir, sepanjang tidak mengandung unsur mineral golongan A maupun B dalam skala yang berarti dari segi ekonomi pertambangan. (Sukandarrumidi,1999)

Terminologi bahan galian golongan C yang sebelumnya diatur dalam UU No 11 Tahun 1967 telah diubah berdasarkan UU No 4 Tahun 2009, menjadi batuan, sehingga penggunaan istilah bahan galian golongan $\mathrm{C}$ diganti menjadi batuan.

Peraturan Pemerintah No 23 Tahun 2010 tentang Pelaksanaan Kegiatan Usaha Pertambangan Mineral dan Batubara. Berdasarkan Peraturan Pemerintah ini komoditas pertambangan dikelompokkan dalam 5 golongan yaitu:

1. Mineral Radio aktif antara lain : radium, thorium, uranium.

2. Mineral Logam antara lain lain : emas, tembaga

3. Mineral bukan logam antara lain : intan, bentonit.

4. Batuan antara lain : tanah liat, tanah urug, kerikil galian dari bukit, kerikil sungai, pasir urug.

5. Batubara antara lain : batuan aspal, batubara, gambut.

Istilah Hukum Pertambangan merupakan terjemahan dari bahasa Inggris, yaitu mining law. Hukum Pertambangan adalah : "Hukum yang mengatur tentang penggalian atau pertambangan bijih-bijih dan mineralmineral dalam tanah" (Salim, $2007: 7$ )

Definisi ini hanya difokuskan pada aktifitas penggalian atau pertambangan bijih-bijih. Penggalian atau pertambangan merupakan usaha untuk menggali berbagai potensi-potensi yang terkandung dalam perut bumi. Definisi 
lain dapat di baca dalam Blacklaw dictionary. Hukum Pertambangan adalah ketentuan yang khusus yang mengatur hak menambang (bagian dari tanah yang mengandung logam berharga di dalam tanah atau bebatuan) menurut aturanaturan yang telah ditetapkan.

Hukum pertambangan adalah aturan hukum yang mengatur hubungan hukum antara manusia dengan subyek hukum lain dengan segala sesuatu yang bersangkut paut dengan pertambangan. (Faried, 1997 :67)

Sedangkan Landasan Yuridis pertambangan galian $\mathrm{C}$ adalah sebagai berikut:

a) Ketentuan umum dalam undangundang RI Nomor 4 Tahun 2009 yang dimaksud dengan Pertambangan adalah kegiatan dalam rangka pengusahaan mineral dan batu bara yang meliputi tahapan kegiatan penyelidikan umum, eksplorasi, study kelayakan, kontruksi, penambangan, pengolahan dan pemurnian (produksi), pengangkutan dan penjualan, serta pasca tambang.

b) Perundangan tentang pengelolaan lingkungan hidup Menurut UndangUndang Republik Indonesia Nomor 23 Tahun 1997 Pengelolaan lingkungan hidup adalah upaya terpadu untuk melestarikan fungsi lingkungan hidup yang meliputi kebijaksanaan penataan, pemanfaatan, pengembangan, pemeliharaan, pemulihan, pengawasan, dan pengendalian lingkungan hidup.

c) Undang-Undang Nomor 32 Tahun 2004, kewenangan dalam pemberian izin diserahkan kepada pemerintah daerah (provinsi, kabupaten/kota) dan pemerintah pusat, sesuai dengan kewenangannya.

Penggolongan bahan galian menurut Undang-Undang No. 11 Tahun 1967 tentang Ketentuan-Ketentuan Pokok Pertambangan, dibagi menjadi 3 (tiga) golongan, yaitu:
1. Bahan galian golongan $A$, yaitu bahan galian golongan strategis. Yang dimaksud strategis adalah strategis bagi pertahanan/keamanan negara atau bagi perekonomian negara;

2. Bahan galian golongan $\mathrm{B}$, yaitu bahan galian vital, adalah bahan galian yang dapat menjamin hajat hidup orang banyak;

3. Bahan galian $\mathrm{C}$, yaitu bahan galian yang tidak termasuk kedalam golongan A dan B.

\section{Tinjauan Tentang Studi Kelayakan Bisnis}

Setiap usaha yang dijalankan tentunya akan memberikan dampak positif dan negatif. Dampak positif dan negatif ini akan dapat dirasakan oleh berbagai pihak, baik bagi pengusaha itu sendiri, pemerintah, ataupun masyarakat luas. Lebih dari itu yang terpenting adalah ada yang mengelola dan mengatur sumber daya alam yang belum terjamah. Sebaliknya, dampak negatifpun tidak akan terlepas dari aspek ekonomi, misalnya eksplorasi sumber daya yang berlebihan, masuknya pekerja dari luar daerah sehingga mengurangi peluang bagi masyarakat sekitarnya.

Dampak positif dari aspek sosial bagi masyarakat secara umum adalah tersedianya sarana dan prasarana yang dibutuhkan, seperti pembangunan jalan, jembatan, listrik, dan sarana lainnya. Kemudian bagi pemerintah dampak negatif dari aspek sosial adanya perubahan demografi di suatu wilayah, perubahan budaya, dan kesehatan masyarakat.

Dampak negatif dalam aspek sosial termasuk terjadinya perubahan gaya hidup, budaya, adat istiadat dan struktur sosial lainnya (Kasmir, 2009 : 193). Jadi, dalam aspek ekonomi dan sosial yang perlu ditela'ah apakah jika usaha atau proyek dijalankan akan memberikan manfaat secara ekonomi dan sosial kepada berbagai pihak atau sebaliknya. Oleh karna itu, aspek ekonomi dan sosial 
ini perlu dipertimbangkan, karena dampak yang akan ditimbulkan nantinya sangat luas apabila salah dalam melakukan penilaian. Mempertimbangkan dan menilai dampak sosial, ataupun dukungan dari masyarakat di sekitar lokasi.

\section{Amdal dan Konsep Pegelolaan Lingkungan Hidup.}

Lingkungan hidup merupakan salah satu aspek yang sangat penting untuk ditelaah sebelum sebuah investasi atau usaha dijalankan. Sudah barang tentu telaah yang dilakukan untuk mengetahui dampak yang ditimbulkan jika suatu usaha jadi dilakukan, baik dampak negatif maupun dampak positif. Oleh karena itu sebelum suatu usaha atau proyek dijalankan, maka sebaiknya dilakukan terlebih dulu studi tentang dampak lingkungan yang bakal timbul, baik dampak sekarang maupun di masa yang akan datang. Studi itu di samping untuk mengetahui dampak yang bakal timbul, juga mencarikan jalan keluar untuk mengatasi dampak tersebut. Studi inilah yang kita kenal dengan nama Analisis Dampak Lingkungan Hidup (AMDAL). (Kasmir, 2003 : 303)

Pengertian Analisis Dampak Lingkungan (AMDAL) menurut Peraturan Pemerintah Nomor 27 tahun 1999 pasal 1 adalah telaahan secara cermat dan mendalam tentang dampak besar dan penting suatu rencana dan kegiatan. Arti lain analisis dampak lingkungan adalah teknik untuk menganalisis apakah proyek yang akan dijalankan akan mencemarkan lingkungan atau tidak dan jika ya, maka diberikan jalan alternatif pencegahannya.

Pengutamaan telaah AMDAL secara khusus adalah meliputi dampak lingkungan sekitarnya, baik di dalam maupun di luar suatu usaha atau proyek yang akan dijalankan. Arti keberadaan suatu usaha atau proyek akan mempengaruhi kegiatan-kegiatan yang berada di sekitar rencana lokasi, baik dampak rencana usaha ataupun kegiatan terhadap kegiatan-kegiatan yang sudah ada.

Sasaran utama dari AMDAL adalah untu menjaga kelestarian lingkungan hidup. Atau dengan kata lain untuk menjaga lingkungan hidup dari segala bentuk pengrusakan, pencemaran atau kegiatan yang merugikan kelestarian lingkungan hidup yang pada akhirnya akan merugikan manusia itu sendiri. Dalam rangka menjaga dan menyelamatkan lingkungan hidup, maka perlu dilakukan studi AMDAL yang benar.

\section{METODE}

Untuk menjawab permasalahan yang dikemukakan dalam penelitian ini, maka metode penelitian yang digunakan adalah deskriptif kualitatif yaitu mengumpulkan data yang telah ada kemudian data itu dikelompokkan ke dalam kategori-kategori berdasarkan perumusan masalah, jenis data tersebut dengan tujuan dapat menggambarkan permasalahan yang diteliti kemudian dianalisa dengan menggunakan pendapat atau teori para ahli yang relevan. penelitian ini adalah penelitian lapangan (field research). Sedangkan subyek penelitian ini adalah para penambang yang melaksanakan penambangan batu gunung, sedangkan yang menjadi obyeknya adalah dampak penambangan batu gunung di Desa Merangin Kecamatan Kuok ditinjau menurut ekonomi Islam. Populasi dalam penelitian ini berjumlah 75 orang yang terdiri dari masyarakat yang melakukan penambangan batu gunung tersebut. karena populasinya sedikit maka digunakan metode total sampling (semua populasi dijadikan sampel). Data primer adalah data yang diperoleh langsung dari tempat penelitian yaitu para penambang batu gunung. kemudian Data sekunder adalah data pendukung yang diperoleh dari data kepustakaan dari literatur-literatur atau kitab-kitab yang ada hubungannya dengan permasalahan yang diteliti. 
metode pegumpulan datanya adalah : Pertama, Observasi yaitu pengumpulan data yang penulis lakukan dengan cara mengamati secara langsung dilapangan untuk mendapatkan gambaran secara nyata tentang kegiatan yang diteliti. Kedua, Wawancara yaitu bertanya secara langsung kepada para penambang batu gunung dan masyarakat yang berda disekitar area penambangan batu gunung. Ketiga, angket yaitu metode pengumpulan data melalui pertanyaan yang disebarkan oleh penulis ke para penambang batu gunung.

\section{HASIL}

\section{Pelaksanaan Penambangan Batu Gunung di Desa Merangin Kecamatan Kuok}

Penambangan batu gunung di Desa Merangin Kecamatan kuok ini di mulai pada tahun 2001. lokasi atau tanah penambangan batu gunung ini adalah milik pemerintah Kabupaten Kampar. Dari awal penambangan tidak ada penolakan dari masyarakat ataupun pengurus Desa atas pelaksanaan penambangan batu gunung ini karena para penambang rata-rata masyarakat sekitar atau yang berada di Desa Merangin. Walaupun sebelumnya sudah ada teguran dari pemerintah Kabupaten Kampar yang langsung turun kelapangan atau lokasi penambangan batu gunung ini yaitu Bupati Kampar Burhanudidn Husein yang menjabat pada periode 2006-2011 kemaren. Artinya penambangan batu gunung di Desa Merangin Kecamatan Kuok ini tidak memiliki izin dari pemerintah Kabupaten Kampar akan tetapi aktivitas penambangan batu gunung ini tetap dilaksanakan sampai sekarang.

Saat ini penambangan batu gunung di Desa Merangin Kecamatan Kuok merupakan pertambangan rakyat karena dilakukan secara manual degan alat yang sederhana dan dilakukan untuk memenuhi kebutuhan hidup sehari-hari.
Kegiatan penambangan batu gunung dilaksanakan setiap hari, biasanya penambang bekerja mulai jam 07.00 dan selesai jam 17.00 WIB, namun bila cuaca tidak mendukung terutama pada saat hujan deras maka para penambang menghentikan kegiatannya karena khawatir dengan keselamatan mereka.

Berdasarkan hasil wawancara dengan penambang, mengatakan bahwa menjadi buruh atau tenaga kerja dipenambangan batu gunung ini lebih menguntungkan dari pada buruh tani atau menyadap karet. (Syamsul, Wawancara, Desa Merangin, 16 Maret 2013)

Faktor pendidikan masyarakat juga berpengaruh. sebahagian besar masyarakat Desa Merangin adalah lulusan SD atau tidak lulus SD sehingga pemahaman mereka tentang lingkungan hidup sedikit sekali. Yang ada dalam pemikiran mereka hanyalah bagaimana caranya memenuhi kebutuhan hidup mereka sehari-hari dengan mendapatkan uang melalui pekerjaan yang dapat diharapkan hasilnya secara nyata. Keberlanjutan dari usaha mereka pada jangka panjang tidak menjadi pemikiran mereka. Ada sebagian dari tenaga kerja yang mengerti tentang lingkungan hidup namun karena tekanan ekonomi membuat mereka terpaksa tetap mengambil keputusan untuk bekerja di penambangan batu gunung karena tidak mendapatkan pekerjaan yang lain.

Sarana dan prasarana yang kerja yang digunakan para penambang adalah sebagai berikut:

1. Linggis, berfungsi sebagai meretakkan batu yang menempel di gunung dan memecahkan batu yang besar.

2. Palu, berfungsi sebagai menokok pahat yang digunakan untuk memecahkan batu.

3. Pahat, berfungsi sebagai memecahkan batu.

4. Linggis, palu dan pahat yang digunakan untuk memecahkan batu. 
5. Tali/tambang dan tangga, berfungsi untuk menyangga dan keamanan bekerja yang menggali dari bagian atas.

6. Topi atau caping, berfungsi sebagai penahan panasnya matahari.

Pendapatan dari kegiatan

penambangan batu gunung termasuk sangat besar apabila nilai kerugian diabaikan atau tidak dihitung. Pendapatan dari hasil penambangan ini hanya untuk para penambang dan tidak ada untuk kas desa karena desa tidak ada mengatur atau pun menetapkan kalau hasil pendapatan penjualan batu gunung sebahagiannya untuk desa. Penambang yang dimaksud disini adalah para pekerja tambang batu gunung tersebut. Harga penjualan batu tiap truk itu tergantung berapa kubiknya batu yang di isi dalam truk tersebut, batu tersebut terkadang di jual $\mathrm{Rp} 110.000$ atau Rp 120.000 / kubik. kalau dalam satu truk batu di isi 5 (lima) kubik dan di jual dengan harga Rp 120.000 maka pendapatannya Rp.600.000 / truk (Rp.120.000 x 5 = Rp. 600.000). Tetapi apabila batu dijual dengan harga Rp. 110.000 / kubik maka Rp. $110.000 \times 5=$ Rp. 550.000 / truk.

Semua hasil pendapatan penambangan tersebut semuanya untuk para penambang. Tidak ada memberikan kontribusi kepada pemerintah daerah Kabupaten Kampar karena memang penambangan batu gunung ini tidak memiliki izin dari pemerintah Kabupaten Kampar, walaupun peraturan tentang pembinaan dan penertiban usaha pertambangan ini sudah dilakukan baik peraturan tertulis ataupun tidak tetapi pemerintah masih kesulitan dalam pembinaan, pengawasan dan penertiban terhadap para penambang.

\section{Dampak Kegiatan Penambagan Batu Gunung di Desa Merangin Kecamatan Kuok}

$\begin{array}{lrr} & \text { Setiap aktivitas ataupun pekerjaan } \\ \text { pasti mempunyai dampak yang } & \text { aktivitas } \\ \text { ditimbulkan apalagi }\end{array}$

penambangan, terutama dampaknya terhadap lingkungan.

\section{Dampak terhadap lingkungan.}

1. Terjadi polusi udara berupa debu.

2. Resiko adanya longsor karena tebing tidak berteras.

3. Hilangnya sebagian pemandangan yang indah dan sejuk di lereng Gunung.

4. Adanya lahan yang tidak teratur karena adanya lubang-lubang bekas galian.

5. Berkurangnya kenyamanan masyarakat pengguna jalan karena jalan rusak dan berdebu.

6. Sebagian masyarakat merasa takut terjadi malapetaka/bencana.

7. Sebagian masyarakat yang mengerti tentang arti lingkungan merasa kecewa dan sedih dengan adanya penambangan batu di desa mereka.

\section{Dampak sosial ekonomi masyarakat. Dampak Positif}

Dampak positif pada aspek sosial eknomi dengan adanya kegiatan penambangan batu gunung ini dirasakan oleh sebagian masyarakat Desa Merangin, yaitu mereka yang bekerja di lokasi penambangan batu dan juga masyarakat umum di luar lokasi penambangan, yaitu sebagai berikut :

\section{Dampak bagi masyarakat penambang :}

1. Pengurangan jumlah pengangguran karena sebagian masyarakat bekerja menjadi tenaga kerja di penambangan batu, baik menjadi buruh tambang/penjual makanan, baik lakilaki maupun perempuan. Sebagian besar pengangguran yang berkurang karena menjadi tenaga kerja di penambangan batu adalah tenaga kerja laki-laki. Perbandingan tenaga kerja laki-laki dengan perempuan adalah 10 laki-laki dan 1 perempuan. Adanya kegiatan penambangan batu telah menciptakan lapangan kerja yang cukup besar bagi sebagian masyarakat Desa Merangin. 
2. Peningkatan penghasilan masyarakat yang dahulunya menjadi buruh tani dan ada juga yang bekerja sebagai supir angkutan umum. Berdasarkan wawancara, sewaktu mereka menjadi buruh tani ataupun penghasilan yang didapatkan tidak pasti namun setelah menjadi pekerja di penambangan batu penghasilan dari penjualan batu dapat dipastikan tiap hari pasti ada. Begitu juga dengan masyarakat yang dahulunya menjadi buruh tani, upah mereka lebih besar dengan menjadi buruh tambang. Kegiatan penambangan batu secara nyata meningkatkan penghasilan dari sebagian masyarakat Desa Merangin. Kaum perempuan yang berjualan makanan keliling di lokasi penambangan juga meningkat penghasilannya. Mereka mengatakan bahwa penambangan batu sangat membantu ekonomi mereka.

3. Adanya ketenangan bagi sebagian kepala keluarga karena dengan bekerja di penambangan batu ada penghasilan yang mereka peroleh untuk menghidupi keluarga mereka. Sebelumnya mereka adalah pengangguran.

\section{Dampak bagi masyarakat bukan penambang}

Masyarakat yang lewat ataupun melintasi jalan lintas Riau-sumbar merasakan jaminan keselamatan dari para pencuri ataupun perampok dijalan karena dulu jalannya sempit tetapi karena adanya penambangan batu gunung ini adanya pelebaran jalan sehingga bagi pengendara sepeda motor ataupun mobil bisa aman melalui jalan tersebut, karena dengan adanya para penambang yang bekerja membuat para pencuri ataupun perampok berpikir dua kali lipat kalau hendak melakukan kejahatan.

\section{Dampak Negatif}

Dampak negatif pada aspek sosial ekonomi karena adanya kegiatan penambangan bstu dirasakan oleh masyarakat penambang dan juga masyarakat umum di luar lokasi penambangan, yaitu sebagai berikut:

\section{Dampak pada masyarakat penambang}

1. Kurangnya keamanan saat bekerja sering mengakibatkan adanya kecelakaan kecil pada sebagian tenaga kerja sehingga mereka mengeluarkan biaya tambahan untuk mengobati luka. Apabila luka yang mereka derita termasuk berat, misalnya harus diamputasi bagian kaki/tangan atau mengalami patah tulang maka mereka tidak bisa bekerja kembali dan menjadi pengangguran, secara ekonomi tidak menguntungkan bagi mereka. Secara sosial, timbul adanya perasaan kurang berharga di mata keluarga dan mengalami patah semangat karena dengan kecacatan yang mereka alami membuat mereka tidak bisa bekerja lagi seperti semula.

2. Sebagian pekerja tidak menggunakan penutup mata dan hidung saat bekerja sehingga apabila tanah dan pasir disertai debu jatuh dari bagian atas sering mengakibatkan mata mereka kotor dan menjadi sakit, serta adanya gangguan pernafasan walau tidak berat.

\section{Dampak bagi masyarakat bukan penambang}

1. Sebagian masyarakat yang mengerti tentang arti lingkungan merasa kecewa dan sedih dengan adanya penambangan batu di desa mereka. Mereka tidak berani membayangkan desa mereka akan menjadi seperti apa bila kegiatan penambangan batu makin meluas.

2.Berkurangnya kenyamanan para pengguna jalan akibat polusi udara, mereka harus menutup muka supaya terhindar dari debu yang mengenai hidung dan mata.

\section{Tinjuan Ekonomi Islam Terhadap Penambangan Batu Gunung di Desa Merangin Kecamatan Kuok}

Islam mendorong umatnya untuk mencari rezki yang berkah, mendorong berproduksi, menekuni aktivitas ekonomi diberbagai bidang usaha seperti 
pertanian, perkebunan, perdagangan, industri maupun pertambangan. Manusia pada dasarnya adalah khalifah dimuka bumi. Islam memandang bahwa bumi dengan segalag isinya merupakan amanah Allah kepada sang khalifah agar dipergunakan sebaik-baiknya bagi kesejahteraan bersama.

Usaha penambangan batu gunung di Desa Merangin Kecamatan Kuok merupakan salah satu wahana dan prasarana bagi masyarakat yang bisa merangsang mereka lebih giat bekerja dan berusaha. Keberadaan usaha penambangan batu gunung ini telah bisa menyerap tenaga kerja dan hal ini berarti telah ikut andil dalam mengurangi pengangguran di Desa Merangin. Disamping itu keberadaan usaha penambangan batu gunung ini juga telah berperan aktif untuk membentuk pekerja menjadi manusia berproduktif karena telah bisa memanfaatkan waktunya untuk meningkatkan produktifitas produksi. Akan tetapi, usaha penambangan ini juga berdampak terhadap kerusakan lingkungan.

Dari pemaparan diatas bahwa secara umum, usaha penambangan batu gunung di Desa Merangin kecamatan Kuok, menurut penulis belum sejalan dengan syariat Islam, karena Islam melarang setiap pekerjaan yang merugikan masyarakat dan menggangu kenyamanan serta menyulitkan orang lain, dan pekerjaan merusak, seperti merusak lingkungan, merusak alam sekitar, merusak makhluk lainya dan juga karena akibat yang ditimbulkannya. Sedangkan akibat yang disebabkan penambangan batu gunung ini diantaranya kerusakan lingkungan dan untuk jangka panjang bisa terjadi longsor. Sebagaimana firman Allah SWT yang berbunyi :

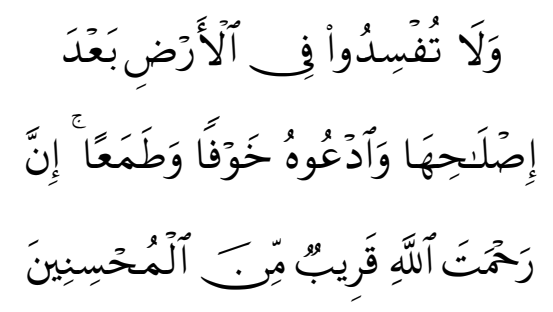

Artinya:"Dan janganlah kamu membuat kerusakan di muka bumi, sesudah (Allah) memperbaikinya dan Berdoalah kepada-Nya dengan rasa takut (tidak akan diterima) dan harapan (akan dikabulkan). Sesungguhnya rahmat Allah Amat dekat kepada orang-orang yang berbuat baik' (QS.Al A'raf (7):56)

Hal ini selaras dengan kaidah usul fiqh yang berbunyi :

"Menolak kerusakan diutamakan ketimbang mengambil kemaslahatan" (Syarifudin, 2009 : 430)

Dari kaidah Usul Fiqh diatas dapat disimpulkan bahwa suatu pekerjaan itu lebih baik menolak kerusakan dibandingkan mengambil kemaslahatan yang akhirnya mengandung banyak kemudharatan yang dapat merugikan baik segi fisik, materi, sosial ataupun masyarakat.

\section{SIMPULAN}

Dari hasil penelitian, maka diperolah kesimpulan sebagai berikut :

Pelaksanaan penambangan batu gunung di Desa Merangin Kecamatan Kuok menggunakan alat-alat sederhana (manual) dan aktivitas penambangan batu gunung ini tidak memiliki Izin Usaha dari Pemerintah Kabupaten Kampar.

Penambangan batu gunung di Desa Merangin ini disamping mempunyai dampak positif bagi ekonomi juga mempunyai dampak negatif, terutama dampak negatif pada kerusakan lingkungan.

Menurut ekonomi Islam penambangan batu gunung di Desa 
Merangin Kecamatan Kuok ini dalam kegiatannya tidak sesuai dengan prinsip Ekonomi Islam karena setiap pekerjaan yang merugikan dan mengganggu kenyamanan orang lain dan pekerjaan merusak, seperti merusak lingkungan atau alam sekitar ataupun merusak lingkungan sosial, masyarakat dan lingkungan fisik. Seharusnya didalam melakukan produksi hendaklah tidak melanggar kaidah-kaidah produksi agar terjaga keseimbangan antara pengusaha, pemerintah dan masyarakat dan tetap terjaganya kelestarian lingkungan hidup. Supaya mendapat keberkahan dalam menjaga bumi Allah SWT.

Adapun saran yang kepada pemerintah dan masyarakat supaya bekerjasama untuk mengatasi kerusakan lingkungan akibat penambangan batu gunung ini, perlu adanya pengawasan oleh instansi terkait yang dilakukan secara periodik untuk mengembalikan keadaan lingkungan yang baik dan serasi dan juga perlu mereklamasi daerah yang sudah digali sehingga lahan tersebut kembali menjadi produktif. Dan diharapkan kepada pemerintah kalau bisa menyediakan lapangan pekerjaan baru agar masyarakat bisa memiliki pekerjaan lain sehingga bisa mengatasi kerusakan lingkungan lebih jauh lagi.

Serta saran kepada Masyarakat agar menyampaikan kritik dan saran kepada pengelola penambangan batu gunung terkait masalah dampak yang ditimbulkan oleh usaha tersebut.

\section{DAFTAR RUJUKAN}

Adiwarman Karim. (2007). Ekonomi Mikro Islam, Jakarta: PT Raja Grafindo Persada.

Akhmad Mujahidin. (2007). Ekonomi Islam, Jakarta: PT Raja Grafindo Persada.

Ali faried. (1997). Hukum Tata Pemerintahan dan Proses Legislatif Indonesia, Jakarta: Raja Grafindo Persada.
Amir Syarifudin. (2009). Ushul Fiqhi, Jakarta: Kencana

Departemen Agama RI. (2002). Al-qur'an dan Terjemahan, Semarang : PT Hidakarya Agung Jakarta.

Haryanto. (2008). Pertambangan: Berkah atau Tulah?, Yogyakarta: Citra Aji Parama

Kasmir, Jakfar. (2003). Studi Kelayakan Bisnis, Jakarta: Kencana Prenada Media Group

Mawardi. (2007). Ekonomi Islam, Pekanbaru : Alaf Riau.

Muh Said. (2008). Pengantar Ekonomi Islam, Pekanbaru, Suska Press.

Salim. (2007). Hukum Pertambangan di Indonesia, Jakarta: Raja Grafindo Persada.

Sukandarrumidi. (1999). Bahan Galian Industri, Yogyakarta: Gadjah Mada University Press.

Qardhawy, Yusuf. (2000). Halal dan Haram. Jakarta:Robbani Press.

SYARIKAT : Jurnal Rumpun Ekonomi Syariah Volume 1, Nomor 2, Desember 2018 